\title{
Effect of Preharvest Carbon Dioxide Enrichment on the Postharvest Quality of Tomatoes
}

\author{
Md. Shahidul Islam, Toshiyuki Matsui and Yuichi Yoshida \\ Department of Agroindustrial Sciences, Faculty of Agriculture, Kagawa University, Miki-cho, Kagawa 761-07
}

\begin{abstract}
Summary
The effect of preharvest application of elevated $\mathrm{CO}_{2}$ throughout the fruit growing period on organic acid, sugar content, acid invertase activity $(\beta$-fructofuranoside fructohydrolase, EC 3.2.1.26), and color quality in tomato (Lycopersicon esculentum Mill. cv. Momotaro) fruit during storage at $20^{\circ} \mathrm{C}$ was determined.

The $\mathrm{CO}_{2}$-enriched tomato fruits contained significantly lower concentrations of citric, malic and oxalic acids, but had significantly higher reducing sugars and acid invertase activity at harvest and during storage. The concentration of these acids decreased with storage, whereas the activity of acid invertase and reducing sugar contents increased in the treated fruits; they were relatively constant in the control fruits. Furthermore, the elevated $\mathrm{CO}_{2}$ resulted in a deeper red color during storage.
\end{abstract}

\section{Introduction}

Organic acids and sugars comprise the majority of the total dry matter contents of tomato (Lycopersicon esculentum Mill.). Citrate is usually the predominant acid in tomato fruits and depend. ing upon variety, environment, and fruit age (Davies, 1965; Stevens, 1972) it comprises 40 to $90 \%$ of the organic acids. The concentration of malate, the other major organic acid, ranges from 10 to $60 \%$ of that of citrate, depending largely on the variety (Davies, 1965). These organic acids are crucial to the flavor and processing character. istics of tomatoes.

Tomatoes also contain higher levels of fructose and glucose than that of sucrose (Garvey and Hewitt, 1991; Miron and Schaffer, 1991). In the genera of Lycopersicon, Manning and Maw (1975) reported that the activity of soluble invertase was higher in L. esculentum compared to other species. There is evidence that increased invertase activity is associated with increased concentrations of hexoses and generally with decreased concentrations of sucrose (Lyne and Rees, 1971; Ricardo and Rees, 1970).
Atmospheres containing elevated levels of $\mathrm{CO}_{2}$ are known to inhibit fruit ripening (Buescher, 1979). The application of $\mathrm{CO}_{2}$ to delay ripening of tomatoes could be performed easily and inexpensively, but several reports have indicated that tomatoes are susceptible to $\mathrm{CO}_{2}$ injury (Bedrosian and Schiffman, 1978; Parsons et al., 1970). Most investigations on the influecne of $\mathrm{CO}_{2}$ on tomatoes have been conducted with mature-green fruits, at reduced temperatures and in combination with reduced $\mathrm{O}_{2}$ levels.

The beneficial effects of $\mathrm{CO}_{2}$ enrichment during the growing period to yield, growth rate, trans. piration, and photosynthesis have been reported by several authors (Calvert and Slack, 1975; Hartz et al., 1991; Kimball and Mitchell, 1979). To our knowledge, no published information is available on the effect of preharvest $\mathrm{CO}_{2}$ enrichment on the constituents of tomato fruit during storage. The purpose of this study was to determine the effect of preharvest application of elevated $\mathrm{CO}_{2}$ throughout the fruit growing period on the organic acids, sugar contents, acid invertase activity, and color quality in tomato fruits during storage.

Received for publication 13 January 1995. 


\section{Materials and Methods}

\section{Plant materials and cultural method}

Tomato cv. Momotaro was grown in greenhouses at the Department of Agroindustrial Sciences, Faculty of Agriculture, Kagawa University, Japan from August 1993 to March 1994. The seeds were sown on 27 August; 14 plants were transplanted on $4 \mathrm{~m}$ NFT (nutrient film technique) channel in two greenhouses on 28 September. The electrical conductivity and $\mathrm{pH}$ of the nutrient solution was maintained at $1.3 \sim 1.5 \mathrm{mS} \cdot \mathrm{cm}^{-1}$ and $5.5 \sim$ 6.5 , respectively. The concentrations ( $\mathrm{mM}$ ) of basic elements in the solution were: $\mathrm{NO}_{3}{ }^{-}=8.0 ; \mathrm{H}_{2} \mathrm{PO}_{4}{ }^{-}$ $=0.7 ; \mathrm{SO}_{4}{ }^{2-}=1.0 ; \mathrm{K}^{+}=4.0 ; \mathrm{Ca}^{2+}=2.0 ; \mathrm{Mg}^{2+}=$ 1.0. $\mathrm{CO}_{2}$ enrichment was done by supplying liquid $\mathrm{CO}_{2}$ through a magnetic bulb controlled by a personal computer (NEC, PC-9801 UV11) connected to an infrared gas analyzer (COS, GH-250E) through A/D converter (Oga Electric, MIF-198). Application of elevated $\mathrm{CO}_{2}$ began on 20 October. immediately after crop establishment and continued until the end of sampling on 15 February, 1994. During the growing period the $\mathrm{CO}_{2}$ in the enriched greenhouse was $700 \sim 900$ ppm, whereas that in the control was $250 \sim 400$ ppm. After anthesis, each flower was treated with $p$-chlorophenoxy acetic acid (PCPA) for uniform fruit setting. The mean temperature during the $\mathrm{CO}_{2}$ enrichment is presented in Fig. 1. Uniformly red fruits of the same age were randomly picked $90 \pm$ 5 days after anthesis on 5, 10 and 15 February, 1994 , in the test and control greenhouses. The samples were stored at $20^{\circ} \mathrm{C}$ and $80 \sim 90 \%$ relative humidity, controlled by an automatic vapour regulator (Hitachi, V-50D) to prevent water loss. Ten fruits (sampled on 5 February) were used in each replication for measurement of fruit weight and color. Sugars, invertase activity, and organic acid contents were analyzed with 3 fruits in one replication at $0,5,10$ and 15 days after storage. After 15 days of storage the fruits in both treatments deteriorated and no longer for analyzed.

\section{Enzyme extraction}

A 10 gram sample of tomato was mixed with 1 $\%$ polyclar AT $(w / w)$ and $1 \mathrm{~g}$ sea sand and homogenized with $10 \mathrm{ml}$ of cold $0.2 \mathrm{M}$ citratephosphate buffer (CP, pH 5.0). The resulting

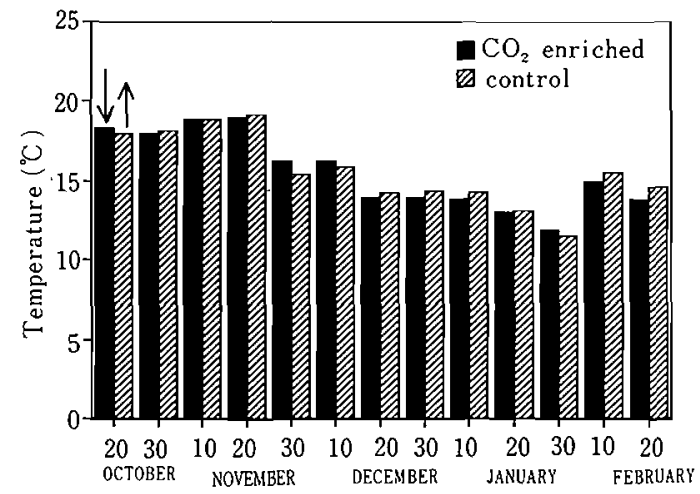

Fig. 1. Mean temperatures during the experiment $(\downarrow$, start of $\mathrm{CO}_{2}$ enrichment and $\uparrow$, first flowering date; each point represents the mean temperature over 10 days).

homogenate was filtered through four layers of cotton cloth, and the filtrate was centrifuged at $11,000 \times g$ for $10 \mathrm{~min}$. The supernatant was dialyzed with $5 \mathrm{mM}$ of the above buffer for $12 \mathrm{hr}$; the innner solution was designated as the soluble fraction (SF). The pellet was dissolved in $10 \mathrm{ml}$ of $0.2 \mathrm{M} \mathrm{CP}$ buf containing $0.2 \mathrm{M}$ of $\mathrm{NaCl}$ for about $24 \mathrm{hr}$ and then centrifuged and dialyzed as above; the dialyzed solution was designated as cell wall bound fraction (CWBF) (Hisajima and Arai, 1978). These extractions were carried out at $0 \sim 4{ }^{\circ} \mathrm{C}$.

\section{Enzyme assays}

The standard assay medium for acid invertase consisted on $80 \mathrm{mM} \mathrm{CP}$ buf $(\mathrm{pH} 5.0), 100 \mathrm{mM}$ sucrose, and an appropriate amount of enzyme solution for a total volume of $0.5 \mathrm{ml}$; the blank contained no sucrose. The assay mixture was incubated at $45^{\circ} \mathrm{C}$ for $15 \mathrm{~min}$, cooled, and neutralized. Somogyi's copper reagent (1952) was added to the mixture which then boiled for $10 \mathrm{~min}$. On cooling, the reducing sugars were quantified. Soluble protein content was determined using the method of Lowry et al. (1951) with bovine serum albumin as the standard. The enzyme activity was expressed as the amount of glucose produced per min per $\mathrm{mg}$ of protein.

Determination of organic acids and soluble sugars by HPLC

Sugar extractions were carried out at $0{ }^{\circ} \sim 4^{\circ} \mathrm{C}$ to prevent the breakdown of sucrose (Matsui and 
Kitagawa, 1988), because cultivated tomatoes have a higher invertase activity (Yelle et al., 1991). Fifteen grams of fruit tissue were mixed with $1 \mathrm{~g}$ sea sand and homogenized. Fifty $\mathrm{ml}$ of cold distilled water were added to the homogenate and the mix. ture centrifuged at $11,000 \times g$ for $10 \mathrm{~min}$ at $2{ }^{\circ} \mathrm{C}$. The mixture was filtered through polyether sulfone membrane filter $(0.45 \mu \mathrm{m}$ pore size) and the filtrate was analyzed for organic acids and soluble sugars by high performance liquid chromatography (HPLC). For organic acids the column $(8 \mathrm{~mm}$ ID $\times 500 \mathrm{~mm}$ ) was packed with Hitachi custom IonExchange Resin \# 2618. The mobile phase was $0.05 \%$ phosphoric acid adjusted to the flow rate of $0.8 \mathrm{ml} \cdot \mathrm{min}^{-1}$. The pressure was $13 \mathrm{~kg} \cdot \mathrm{cm}^{-2}$ and the temperature was $60{ }^{\circ} \mathrm{C}$. The ultraviolet detector was set at $210 \mathrm{~nm}$. For soluble sugars, an aliquot was passed through a stainless steel column $(10.7 \mathrm{~mm} \mathrm{ID} \times 300 \mathrm{~mm})$ packed with silica gel (Gel pack C 610); water, the mobile phase, was pumped through the column at a flow rate of 1.0 $\mathrm{ml} \cdot \mathrm{min}^{-1}$. The pressure was adjusted to $9 \sim 10$ $\mathrm{kg} \cdot \mathrm{cm}^{-2}$ and the temperature to $60{ }^{\circ} \mathrm{C}$. A RI monitor (Hitachi L-3300) was used to record the peak heights and retention times of the compounds in the samples and the authentic reagents used as standards.

\section{Analysis of color}

The fruit color was monitored by measuring the L, a, and b values where L(lightness); a, red (lycopene and other carotenoids), and b, green (chlorophyll) (Baldwin et al., 1991). A digital color difference meter (Nippon Denshoku ND-101 DP) with standard plate $(\mathrm{L}=96.9, \mathrm{a}=-0.1$ and $\mathrm{b}=$ $0.5)$ was used for color analysis.

\section{Statistics}

A completely randomized design with three replications was adopted. Data for the different parameters were analyzed with the help of two softwares CORMAT and STATISTICS. The level of significance was calculated from the $\mathrm{F}$ value of ANOVA.

\section{Results and Discussion}

\section{Effect on shelf-life}

No difference was observed in the shelf-life between preharvest $\mathrm{CO}_{2}$-enriched and control fruits.
In both treatments, the fruits lasted up to 15 days, after which they decayed rapidly.

\section{Fruit weight}

At harvest, tomatoes grown in $\mathrm{CO}_{2}$ enriched greenhouse weighed $328 \mathrm{~g}$ compared to $303 \mathrm{~g}$ in the control (Fig. 2). Calvert and Slack (1975) and Kimball and Mitchell (1979) reported similar find. ings. During the storage period, no significant difference existed in weight loss between the treatments, but the control fruits lost $5 \%$, whereas the treated fruits lost $3 \%$ after 15 days in storage.

\section{Organic acid content}

The preharvest $\mathrm{CO}_{2}$ enrichment significanlty decreased organic acids contents in the fruits during storage (Fig. 3). Citric and malic acid contents reached a maximum at harvest and then declined during storage; citric acid concentration was consistently higher than malic acid throughout the storage priod. A small amount of oxalic acid was present and followed a pattern similar to that of malic acid. Organic acids usually decline during the ripening process as they are respiratory substrates. Winsor et al. (1962), Knee and Finger (1992), Stuart and Efiuvwevwere (1988), and Davies (1966) observed maximum acid contents at pink stage, but the level subsequently declined with ripening. Stuart and Efiuvwevwere (1988) who stored red tomato fruit at various tempera. tures found that citric, malic and oxalic acid con-

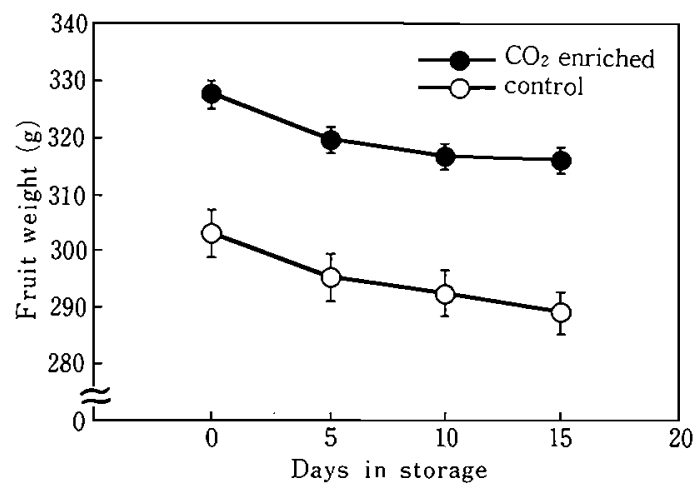

Fig. 2. Effect of preharvest application of elevated $\mathrm{CO}_{2}$ on the fruit weight of tomato during storage. Each point represents the mean of 3 replications (each replicate composites of 10 fruits). Vertical bars indicate SE. 
centrations continued to decrease during storage, reaching the lowest concentrations after 21 days in storage at $19{ }^{\circ} \mathrm{C}$. These results are similar to our findings. Because of its concentration, citric acid contributes the most to the sourness of tomatoes (Stevens, 1972).

\section{Sugar content}

The $\mathrm{CO}_{2}$-enriched tomatoes had significantly higher amounts of fructose and glucose than control fruits had at harvest and subsequently during storage (Fig. 4); no difference between treatments in sucrose contents was found. Fructose level was higher than that of glucose (Fig. 4); these two sugars, which accounted for more than $95 \%$ of the total sugar, were in concentration 50 times higher than that of sucrose after 15 days in storage. Elizabeth et al. (1991) reported similar results. Miron and Schaffer (1991) and Dinar and Stevens (1981) reported that tomato fruits did not accumulate high amounts of sucrose, whereas Oscar and Donald (1988) reported that $\mathrm{CO}_{2}$-enriched fruit during development accumulated more sugar than did the control fruits; these findings are in agreement with ours. Several workers found more reducing sugars in ripe fruit than in fruit

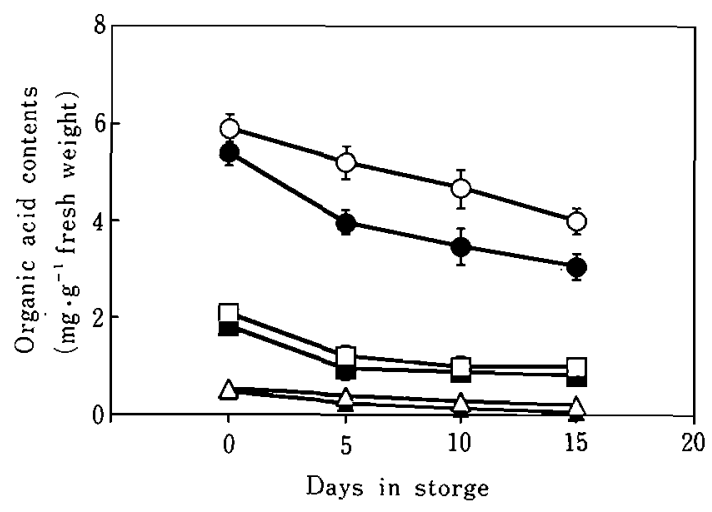

Fig. 3. Changes in organic acid contents in tomato fruit during storage as influenced by preharvest application of elevated $\mathrm{CO}_{2}$. - citric acid $\left(\mathrm{CO}_{2}\right.$ enriched), $-\mathrm{O}$ - citric acid (control), - - malic acid $\left(\mathrm{CO}_{2}\right.$ enriched), $\square-\square$ : malic acid (control), $-\Delta-$ : oxalic acid $\left(\mathrm{CO}_{2}\right.$ enriched), $-\triangle-$ oxalic acid (control). Each point represents the mean of 3 replications (each replicate composites of 3 fruits). Vertical bars indicate SE. picked at green, mature-green or breaker stage (Betancourt et al., 1977 and Kader et al., 1978). In $\mathrm{CO}_{2}$-enriched fruits, reducing sugar content increased during storage, whereas it was relatively constant in controls. This increase is not attributable to the water loss only, because control fruits lost weight more rapidly than did the treated ones.

\section{Acid invertase activity}

Figure 5 shows the effect of preharvest $\mathrm{CO}_{2}$ enrichment on acid invertase activity, which catalyzes the hydrolysis of sucrose to glucose and fructose. Higher activity of soluble acid invertase was observed in the prehavest $\mathrm{CO}_{2}$-treated fruits compared to the control throughout the storage period. Increase in invertase activity was observed from the time of harvest until the last sampling. The acid invertase in the soluble fraction showed a higher activity than that of cell wall-bound fraction throughout the experiment. This pattern is similar to that of kiwifruit (Matsui and Kitagawa, 1988) and tomato (Miron and Schaffer, 1991). Manning and Maw (1975) reported that in the cultivated tomato, acid invertase activity reached its maximum in overripe fruits; similar trends were observed here. The activity of acid invertase had a significant positive correlation with glucose and fructose (Table 1). In the present study, at

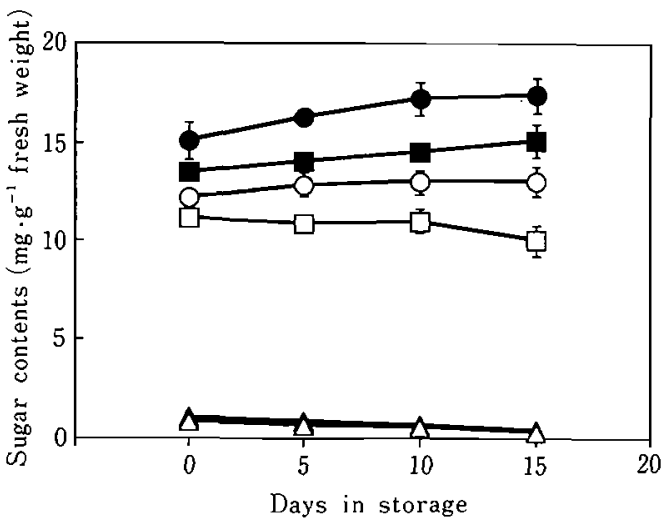

Fig. 4. Changes in sugar contents in tomato fruit during storage as influenced by preharvest application of elevated $\mathrm{CO}_{2}$. - - fructose $\left(\mathrm{CO}_{2}\right.$ enriched). $-\mathrm{O}$ : fructose (control), - - : glucose $\left(\mathrm{CO}_{2}\right.$ enriched), $-\square-$ : glucose (control), - - : sucrose $\left(\mathrm{CO}_{2}\right.$ enriched), $-\triangle$ - sucrose (control). Each point represents the mean of 3 replications (each replicate composites of 3 fruits). Vertical bars indicate SE. 
harvest the $\mathrm{CO}_{2}$-enrichment resulted in higher sugar contents as well as higher acid invertase activity. This is attributed to the faster translocation of photosynthate into the fruits, whereas the increased reducing sugar contents during storage in treated tomatoes could have resulted from the invertase activity.

\section{Color}

' $L$ ' and ' $b$ ' values did not differ significantly between the preharvest $\mathrm{CO}_{2}$-treated and the control

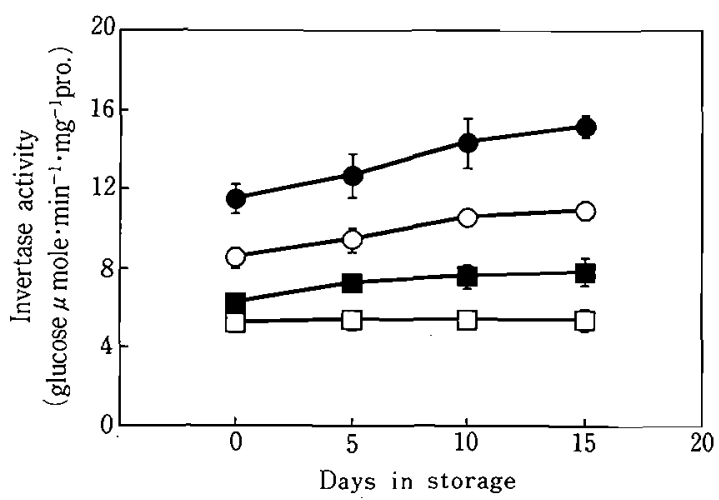

Fig. 5. Acid invertase activity in tomato fruit during storage as influenced by preharvest application of elevated $\mathrm{CO}_{2}$. - Soluble fraction $\left(\mathrm{CO}_{2}\right.$ enriched), $-\mathrm{O}$ : soluble fraction (control), - $\square$ : cell wall-bound fraction ( $\mathrm{CO}_{2}$ enriched), $\square-\square$ - cell wall-bound fraction (control). Each point represents the mean of 3 replications (each replicate composites of 3 fruits). Vertical bars indicate SE. fruits. A significant difference $(p<0.05)$ in the ' $a$ ' values existed between treatments. Fruits from the preharvest $\mathrm{CO}_{2}$ enriched plot were redder than those in the control plot during storage (Fig. 6). We speculate that the higher sugar contents in $\mathrm{CO}_{2}$-enriched fruits may be indirectly responsible for the red color development, comparable to what Takagi et al. (1989, 1994) found with carotenoids (a value) in developing satsuma mandarin.

We conclude that the preharvest application of elevated $\mathrm{CO}_{2}$ concentration increases sugar contents and enhances color in tomato fruits during

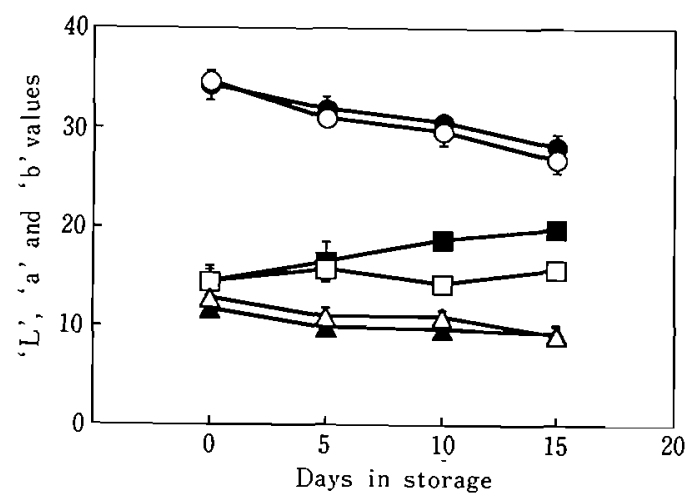

Fig. 6. Hunter ' $L$ ' (lightness), ' $a$ ' (lycopene and other carotenoids) and ' $b$ ' values (chlorophyll) in tomato fruit during storage as influnced by preharvest application of elevated $\mathrm{CO}_{2}$. - - ' $\mathrm{L}$ ' $\left(\mathrm{CO}_{2}\right.$ enriched), $-\mathrm{O}$. ' $\mathrm{L}$ ' (control), 'a' ' $\left(\mathrm{CO}_{2}\right.$ enriched). $-\square-$. 'a' (control), - $\mathbf{A}-$. 'b' $\left(\mathrm{CO}_{2}\right.$ enriched), $-\triangle-:$ : 'b' (control). Each point represents the mean of 3 replications (each replicate composites of 10 fruits). Vertical bars indicate SE.

Table 1. Correlation coefficients ( $r$ ) between sugar contents and acid invertase activi. ties (soluble fraction and cell wall-bound fraction) in tomato fruit during storage $(n=8)$.

\begin{tabular}{lcccc}
\hline Characters & Glucose & Sucrose & $\begin{array}{l}\text { Invertase } \\
\text { activity } \\
\text { (soluble } \\
\text { fraction) }\end{array}$ & $\begin{array}{l}\text { Invertase } \\
\text { activity (cell } \\
\text { wall-bound } \\
\text { fraction) }\end{array}$ \\
\hline Fructose & $0.957^{* *}$ & $-0.048 \mathrm{~ns}$ & $0.958^{* *}$ & $0.988^{* *}$ \\
Glucose & $0.173 \mathrm{~ns}$ & $0.859^{* *}$ & $0.954^{* *}$ \\
Sucrose & & $-0.319 \mathrm{~ns}$ & $-0.076 \mathrm{~ns}$ \\
$\begin{array}{l}\text { Invertase } \\
\text { activity } \\
\begin{array}{l}\text { (soluble } \\
\text { fraction) }\end{array}\end{array}$ & & & $0.946^{* *}$ \\
\hline
\end{tabular}

** Significant at $1 \%$ level, ns $=$ non significant. 
the storage period, compared to fruits exposed to ambient $\mathrm{CO}_{2}$ concentration.

\section{Literature Cited}

Baldwin, E. A., M. O. N. Carriedo and M. G. Moshonas. 1991. Quantitative analysis of flavor and other volatiles and for certain constituents of two tomato cultivars during ripening. J. Amer. Soc. Hort. Sci. $116: 265-269$.

Bedrosian, K. and R. F. Schiffman. 1978. Controlled atmosphere tomato package. U. S. Patent. 4 : 079-152.

Betancourt, L. A., M. A. Stevens and A. A. Kader. 1977. Accumulation and loss of sugars and reduced ascorbic acid in attached and detached tomato fruits. J. Amer. Soc. Hort. Sci. 102 : $721-723$.

Buescher, R. W. 1979. Influence of carbon dioxide on postharvest ripening and deterioration of tomatoes. J. Amer. Soc. Hort. Sci. 104 : 545-547.

Calvert, A. and G. Slack. 1975. Effect of $\mathrm{CO}_{2}$ enrichment on growth, development and yield of glasshouse tomatoes. I. Responses to controlled concen. trations. J. Hort. Sci. $50: 61-71$.

Davies, J. N. 1965. The effect of variety on the malic and citric acid content of tomato fruit. Rep. Glasshouse Crops Res. Inst. 1964 : 139-141.

Davies, J. N. 1966. Changes in the non-volatile organic acids of tomato fruit during ripening. J. Sci. Food. Agric. $17: 396-400$.

Dinar, M. and M. A. Stevens. 1981. The relationship between starch accumulation and soluble solids content in tomato fruits. J. Amer. Soc. Hort. Sci. $106: 415-416$.

Elizabeth, A. B., M. O. N. Carriedo, R. Baker and J. W. Scott. 1991. Quantitative analysis of flavour parameters in six Florida tomato cultivars (Lycopersicon esculentum Mill.). J. Agric. Food Chem. 39 : $1135-1140$

Garvey, T. C. and J. D. Hewitt. 1991. Starch and sugar accumulation in two accessions of Lycopersicon cheesmanii. J. Amer. Soc. Hort. Sci. 116:77-79.

Hartz, T. K., A. Baameur and D. B. Holt. 1991. $\mathrm{CO}_{2}$ enrichment of high-value crops under tunnel culture. J. Amer. Soc. Hort. Sci. 116:970-973.

Hisajima, S. and Y. Arai. 1978. Changes in sugar content and some enzyme activities during the growth of Morning-glory callus. J. Jpn. Soc. Starch Sci. 25 : $163-170$.

Kader, A. A., L. L. Morris, M. A. Stevens and M. A. Holton. 1978. Composition and flavor quality of fresh market tomatoes as influenced by some post. harvest handling procedures. J. Amer. Soc. Hort. Sci. $103: 6-13$.

Kimball, B. A. and S. T. Mitchell. 1979. Tomato yields from $\mathrm{CO}_{2}$ enrichment in unventilated and conven- tionally ventilated greenhouses. J. Amer. Soc. Hort. Sci. $104: 515-520$.

Knee, M. and F. L. Finger. 1992. NADP ${ }^{+}$-malic enzyme and organic acid levels in developing tomato fruits. J. Amer. Soc. Hort. Sci. 117 : 799-801.

Lowry, O. H., N. J. Rosebrough, A. L. Farr and R. Rendall. 1951. Protein measurement with Folin-phenol reagent. J. Biol. Chem. $193: 265-275$.

Lyne, R. L. and T. Rees. 1971. Invertase and sugar content during differentiation of roots of Pisum sativum. Phy tochemistry $10: 2593-2599$.

Manning, K. and G. A. Maw. 1975. Distribution of acid invertase in the tomato plant. Phytochemistry 14 : $1965-1969$

Matsui, T. and H. Kitagawa. 1988. Seasonal changes in invertase activity in relation to sugar content in kiwifruit. J. Japan Soc. Food Sci. Tech. 35 : 856-859.

Matsui, T. and H. Kitagawa. 1988. Effects of pretreatments on sucrose deteremination of persimmon fruit. J. Japan Soc. Food Sci. Tech. 35 : 448-451.

Miron, D. and A. A. Schaffer. 1991. Sucrose phosphate synthase, sucrose synthase, and invertase activities in developing fruit of Lycopersicon esculentum Mill. and sucrose accumulating Lycopersicon hirsutum Humb. and Bonpl. Plant Physiol. 95 : 623-627.

Oscar, A. L. and N. N. Donald. 1988. $\mathrm{CO}_{2}$ enrichment of greenhouse atmospheres. p. 51-52. In: Handbook for vegetable growers. John Wiley and Sons, New York.

Parsons, C. S., R. E. Andreson and R. W. Penney. 1970. Storage of mature green tomatoes in controlled atmospheres. J. Amer. Soc. Hort. Sci. 95 : 791-794.

Ricardo, C. P. P. and A. P. T. Rees. 1970. Invertase activity during the development of carrot roots. Phytochemistry $9: 239-247$.

Somogyi, M. 1952. Notes on sugar determination. J. Biol. Chem. 195: 19-23.

Stevens, M. A. 1972. Citrate and malate concentrations in tomato fruits: genetic control and maturational effects. J. Amer. Soc. Hort. Sci. $97: 655-658$.

Stuart, N. T. and B. J. O. Efiuvwevwere. 1988. Changes in organic acids in chilled tomato fruit (Lycopersicon esculentum Mill.). J. Sci. Food Agric. $44: 309-319$.

Takagi, T., Y. Masuda, T. Ohnishi and T. Suzuki, 1989. Effects of sugar and nitrogen content in peel on color development in satsuma mandarin fruits. J. Japan. Soc. Hort. Sci. 58: 575-580. (In Japanese with English summary).

Takagi, T., H. Mukai, T. Ichikawa and T. Suzuki, 1994. Effects of temperature and sugar accumulation in fruits on color development of satsuma mandarin. J. Japan. Soc. Hort. Sci. $62: 725^{-731 .}$ 
(In Japanese with English summary).

Winsor, G. W., J. N. Davies and D. M. Massey. 1962.

Composition of tomato fruit. III. Juices from whole fruit and locules at different stages of ripeness. J.

Sci. Food. Agric. 13: 108-115.
Yelle, S., R. T. Chetelat, M. Dorais, J. W. DeVerna and A. B. Bennett, 1991. Sink metabolism in tomato fruit. IV. Genetic and biochemical analysis of sucrose accumulation. Plant Physiol. 95 : 1026-1035.

\title{
トマトの収穫後の品質に及ぼす炭酸ガス施用の影響
}

Islam Md. Shahidul ·松井年行 ·吉田裕一

香川大学嶎学部 761-07 香川県木田郡三木町池戸

\begin{abstract}
摘 要
収穫前に炭酸ガスを施用し, 収檴後 $20^{\circ} \mathrm{C} て ゙$ 眝蔵し たトマトに括ける有機酸, 榶含量, 酸性インベルター ゼと果色の影㔁について検討した。炭酸ガス施用トマ ト果実は，眝蔵中の対照区果実と比較してクェン酸, リンゴ酸，シュウ酸含量が有意に低かった。これらの 酸含量は，盯蔵中も減少した。収穛前の炭酸ガス施用

トマトは，収雀時，あるいは眝蔵中も還元糖含量と酸 性インベルターゼ活性が有意に高かった，酸性インベ ルターゼ活性は，貯蔵期間中に增大し，還元糖含量も 炭酸ガス施用で増加したが対照区ではほぼ一定であっ た。さらに，炭酸ガス施用トマトは，処理果実でより 強い赤色となった。
\end{abstract}

